\title{
Notas sobre a crítica-escritura de Haroldo Maranhão, um leitor de Machado 1
}

\author{
Notes about the critical-fiction of Haroldo Maranhão, a reader of Machado de Assis
}

\author{
Paulo Alberto da Silva SALES* \\ Instituto Federal Goiano (IF GOIANO) \\ Zênia de FARIA ${ }^{* *}$ \\ Universidade Federal de Goiás (UFG)
}

\begin{abstract}
RESUMO: Tendo em vista a noção de crítica-escritura a partir dos estudos dos teóricos pósestruturalistas, sobretudo os de Roland Barthes, de Jacques Derrida e de Gilles Deleuze, este artigo apresenta uma leitura do romance Memorial do fim: a morte de Machado de Assis, do escritor paraense Haroldo Maranhão, publicado em 1991. Valendo-se de dados biográficos, ficcionais e teórico-críticos de Machado de Assis, Haroldo Maranhão mesclou, em um mesmo texto, discursos diversos. Para isso, veremos como a narrativa ficcional de Maranhão se serviu dos preceitos pós-estruturalistas para criar, no texto ficcional, uma crítica-escritura a partir da releitura dos textos ficcionais, biográficos e críticos de Machado de Assis.
\end{abstract}

PALVRAS-CHAVE: Crítica-escritura. Haroldo Maranhão. Machado de Assis.

\begin{abstract}
In view of the notion of critical-writing from the post-structuralism studies, about everything of Roland Barthes, Jacques Derrida and Gilles Deleuze, this paper presents a reading of the novel Memorial do fim a morte de Machado de Assis, by the paraense writer Haroldo Maranhão, published in 1991. To be worth about the Machado de Assis biographical, fictional

\footnotetext{
${ }^{1}$ Este artigo apresenta aspectos contidos na introdução da tese de doutorado intitulada "Sob o signo da escritura: ficção-crítica, biografia e história em Haroldo Maranhão", de Paulo Alberto da Silva Sales, defendida na Universidade Federal de Goiás em 2014. Neste artigo, fizemos algumas modificações em relação ao texto original para a melhor compreensão do leitor.

"Pós-doutor em Letras e Linguística - Estudos Literários - pela Universidade Federal de Goiás (2017 2018). Doutor em Letras e Linguística também pela Universidade Federal de Goiás. Docente do Instituto Federal Goiano Campus Hidrolândia, Goiás. E-mail: paulo.alberto@ifgoiano.edu.br.

${ }^{* *}$ Pós-doutora em Literatura Comparada pelo Centre d'Études et de Recherches Comparatistes - Université de Paris III - Sorobonne Nouvelle - France. Doutora em Teoria Literária e Literatura Comparada - pela USP- São Paulo. Docente do Programa de Pós-Graduação em Letras e Linguística da Faculdade de Letras da Universidade Federal de Goiás, Brasil. E-mail: zefirff@ gmail.com.
} 
and theoretical data, Haroldo Maranhão mixed in the same text different speeches. For that, we are going to investigate how the Haroldo Maranhão's novel used the post sctruturalists precepts to create, in the fictional text, a critical writing by the reading of Machado de Assis biographical, fictional and critical texts.

KEYWORDS: Critical writing. Haroldo Maranhão. Machado de Assis.

\begin{abstract}
Ativo/reativo
No que ele escreve, há dois textos. O texto I é reativo, movido por indignações, medos, desaforos interiores, pequenas paranoias, defesas, cenas. O texto II é ativo, movido pelo prazer. Mas ao escrever-se, ao corrigir-se, ao submeter-se à ficção do estilo, o texto I se torna ele próprio ativo; perde então a pele reativa, que só subsiste por placas (em minúsculos parênteses). (BARTHES, 2003, p. 55)
\end{abstract}

\title{
"O que os livros fazem"2
}

Como aprendemos com Roland Barthes, em seus vários estudos, os textos são plurais e possuem várias redes e entradas. Tais redes se desdobram em emaranhados de fios dissonantes que tendem a mesclar, em um mesmo texto, fato e ficção. Essas misturas são constatadas, sobretudo, nas narrativas ficcionais brasileiras da contemporaneidade, que apresentam inúmeras formas “inespecíficas" (GARRAMUÑO, 2014) ao incorporarem, nas suas tessituras, discursos de outros campos do saber, tornando-as híbridas. Barthes, na epígrafe acima, - retirada da obra Roland Barthes por Roland Barthes (2003) - , destaca essa copresença de um texto em outro, ou melhor, de vários elementos de outros textos que, a nosso ver, estão presentes em ficções brasileiras do último quartel do século XX e na primeira década do século XXI. São textos movidos pelo "prazer", ou melhor, são narrativas rememorativas que criam uma dicção semelhante à de grandes mestres da literatura nacional. Em muitos casos, há o retorno de temas, de trechos de obras e mesmo de figuras empíricas de autores no enredo de romances por meio de vários níveis intertextuais, o que revela, nos escritores da contemporaneidade, uma rendição "à ficção do estilo" (BARTHES, 2003). Um exemplo desse tipo de texto é

${ }^{2}$ (MARANHÃO, 2004, p. 81) 
o romance Memorial do Fim: A morte de Machado de Assis, do escritor paraense Haroldo Maranhão, publicado pela primeira vez em 1991, pela editora Marco Zero e, posteriormente, em 2004 pela editora Planeta.

No enredo desse romance, há o embaralhamento de elementos autobiográficos, teórico-críticos, históricos e ficcionais do autor de Memorial de Aires. O Memorial do fim se detém na tentativa sui generis de Maranhão em resgatar a figura de Machado de Assis e de, ao mesmo tempo, entrelaçar aspectos de sua vida e de sua obra em um mesmo texto. Dividido em 53 capítulos que remetem diretamente à forma machadiana de escrita - que foi herdada de Tristram Shandy - , tanto na dicção ficcional e na forma concisa dos capítulos, quanto na enumeração deles em algarismos romanos, o romance ainda apresenta em suas páginas finais um Post Scriptum, no qual Maranhão faz o papel de crítico literário ao examinar seu próprio romance. Nessa parte em específico, o escritor nortista confessa sua paixão pela literatura machadiana e, por meio de suas mais variadas leituras dos romances, contos e de outros textos literários de Machado, Maranhão se revela como um profundo conhecedor do universo ficcional do escritor fluminense e quis, então, homenageá-lo com uma narrativa feita por meio de pastiches ${ }^{3}$, intertextualidades, paródias, citações e principalmente por uma voz irônica - tipicamente machadiana - que, propositalmente, foi utilizada contra seu próprio criador.

Ao adotar o estilo daquele escritor realista - no regaste do niilismo e da ironia melancólica de Brás Cubas - Maranhão retoma os momentos finais da vida de Machado de Assis, mais especificamente após o ano de 1904, ano, esse, marcado pela morte de sua esposa Dona Carolina. Desde então, os anos que se seguem registram um Machado extremamente solitário e ainda mais reservado. A solidão, a dor da perda da companheira e as constantes crises de epilepsia foram se agravando e geraram outros problemas de saúde, o que culminaria na morte de Machado em 29 de setembro de 1908.

Associada à representação dos momentos finais de Machado, a ficção de Maranhão se vale de várias estratégias narrativas que desestruturam e friccionam os gêneros ficcionais e não-ficcionais no texto. Fato e ficção se tornam equivalentes na tessitura do romance e as referencialidades fora do texto são "mero décor" (MARANHÃO, 2004). Além disso, o texto ficcional apresenta um tom hermenêutico ao

\footnotetext{
${ }^{3}$ Segundo Gerárd Genette (1982), o pastiche, assim como a paródia, é um hipertexto no qual se percebe a imitação de um estilo. O diferencial é que, no pastiche, há uma mistura, uma mescla, uma costura e uma bricolagem de códigos cuja função primeira é criar a semelhança pela repetição.
} 
evidenciar, também, por meio de vários narradores - sobretudo na escolha da voz autodiegética - , comentários de natureza crítico-reflexiva sobre a criação literária, além de inúmeras digressões - tão caras a Machado - que refletem sobre o próprio jogo ficcional de Maranhão.

O jogo ao qual nos referimos se constrói a partir da troca de nomes de personagens machadianas com nomes de pessoas reais do convívio do autor de Dom Casmurro. Nesse puzzle, personalidades importantes da história literária e política brasileira passam a transitar e a conviver com personagens que respondem por nomes diversos no enredo. Marcela Valongo, por exemplo, personagem de Memórias Póstumas de Brás Cubas, atende pelo nome de Hilda/Hylda e Fidélia, além do próprio Machado de Assis, que reponde pelo nome de Machado, de Joaquim Maria, Aguiar e de Conselheiro Ayres.

Mediante a tantas questões herméticas presentes em Memorial do Fim, tendo em vista suas múltiplas "teias", para usar um termo empregado pelo crítico da obra de Haroldo Maranhão, Sérgio Alves (2006), além de conter tecidos amalgamados, bricolados, enxertos textuais e tantos outros aspectos no que confere à problematização do gênero romanesco, nos deteremos em algumas especificidades deste texto ficcional que apresenta uma natureza teórico-crítica. Mas, então, como examinar e quais os instrumentos teóricos que a crítica do século XXI utiliza para tratar de romances como Memorial do fim?

\section{"Entre parenthesis"4}

Há várias terminologias e instrumentos de análise que podemos aplicar à narrativa de Maranhão e tantas outras que apresentam questões semelhantes a ela: a noção de metaficção historiográfica, de metaficção pós-moderna, de novo romance histórico, de romance histórico brasileiro contemporâneo e, por fim, a ideia de escritura que, segundo Barthes, seria uma ficção-crítica.

No estudo de Hutcheon (1991), os romances pós-modernos são aquelas narrativas paradoxais por serem autorreflexivas e autoconscientes ao inserirem, em sua própria composição, uma avaliação crítica do labor ficcional e, ao mesmo tempo, convocam a participação ativa do leitor. Além disso, elas se apropriam de acontecimentos,

${ }^{4}($ MARANHÃO, 2004, p. 75) 
personagens e fatos históricos. A essas narrativas, Hutcheon denominou de metaficções historiográficas. Nelas, há a incorporação da "autoconsciência teórica sobre a história e a ficção como criações humanas (metaficção historiográfica) [que] passa a ser a base para seu repensar e sua reelaboração das formas e conteúdos do passado". (HUTCHEON, 1991, p. 22)

No romance Memorial do fim, há vários aspectos da metaficção historiográfica e da própria metaficção, que Hutcheon (1984), em Narcissistic narrative, seu estudo pioneiro sobre o assunto, chamou de "narrativas narcisistas". Essas ficções renegam o realismo formal em prol de uma averiguação mais contida dos meandros e dos engendramentos do fazer ficcional. E, para isso, o leitor é um elemento ativo e participante nos múltiplos processos enunciativos do texto, já que é um coautor. O teor autorreflexivo presente na metaficção já era uma constante nos romances de Machado de Assis, principalmente em Memórias póstumas de Brás Cubas, Esaú e Jacó, Dom Casmurro e Memorial de Aires. Em Memorial do fim, o grau autorreflexivo é ainda mais problematizado, haja vista que Maranhão também se vale da metaficção associada a outras estratégias da narrativa ficcional.

Uma delas é a utilização da forma biográfica para "findar" o Memorial de Aires que ficou "incompleto". A forma inacabada do último romance machadiano, cujo tom da narrativa é autobiográfico e, também, escrita em forma de um diário híbrido, foi uma forte influência ao escritor nortista contemporâneo. Maranhão muniu-se dos signos machadianos, dos aspectos autobiográficos e ficcionais para a composição de sua rapsódia, ou seja, de um texto todo mesclado e composto de partes emendadas e recortadas de fontes distintas cujos eczemas, nessas junções, demonstram uma reelaboração crítica do próprio conceito de biografia tradicional.

Esse hibridismo entre romance/biografia/história promove uma interação entre alta e baixa literatura propiciada pelo novo diálogo entre o fictício, a cultura de massa e a cultura popular. Além desses emaranhados, há, ainda, a mescla de gêneros ficcionais com os gêneros não propriamente ficcionais - como os textos memorialísticos, intimistas e de caráter crítico, como o ensaio, por exemplo. A dimensão híbrida da narrativa Memorial do fim promove o "retorno" de um "machado" feito de palavras e de discursos intercruzados com traços ficcionais da própria ficção machadiana que causam uma 
intranquilidade no leitor ao ler uma "biografia" marcada pelo "fim". A tenaz ironia se manifesta aí, desde o título do romance até o seu findar.

Problematizando, também, a noção de biografia tradicional pela narrativa brasileira contemporânea, Diana Klinger (2013), em Escritas de si, escritas do outro, destaca o "retorno" do autor na ficção brasileira a partir do que ela entende como uma "virada" etnográfica. Ela aponta que é um traço característico da produção romanesca da contemporaneidade a presença da autobiografia e da biografia real do autor empírico em textos que, por outro lado, são literários. Tal mistura propõe um exame de forma descentrada ${ }^{5}$ dos discursos situados na interface entre o real e o heterocosmo da narrativa fictícia. Mas, nessa reelaboração crítica, o romanesco se apropria da biografia não para torná-la um discurso obsoleto haja vista que "o texto 'falha' em pôr uma ordem na vivência caótica e fragmentária da identidade”. (KLINGER, 2013, p. 17)

Obviamente, essas estratégias problematizadoras do romance contemporâneo não são tipicamente latino-americanas. Concordamos com Klinger que Barthes é uma das vozes mais importantes dessas questões híbridas e revigorantes do romance. Ficcionistas como Maranhão foram influenciados, diretamente, pelo nouveau roman français que Leyla Perrone-Moisés (1966) chamou de "romance do campo do possível". O universo significativo tradicional, fechado e mimético, é negado e passa a dar espaço para "um universo onde as coisas e os acontecimentos têm uma pureza inicial, onde eles existem antes de significar". (MOISÉS, 1966, p. 18). Ou melhor, o romance é uma reapresentação, para usar a terminologia barthesiana, uma vez que ele é um presente perpétuo. O texto exclui a crítica tradicional porque ele, em si mesmo, é uma críticaficção-teórica: trata-se, em outras palavras do texto escriptível (BARTHES, 1970; 2010; 2011). Barthes adota essas terminologias para distinguir estas "críticas-escrituras" dos textos representativos, chamados de legíveis $^{6}$, já que nos textos escriptíveis, os eventos e

\footnotetext{
${ }^{5}$ Traduzido do vocábulo francês décentrement, o descentramento trata, segundo Glossário de Derrida, de Silviano Santiago (1976, p. 16), de uma leitura intertextual, vinculada ao jogo, a mescla, ao suplemento e se opõe aos conceitos clássicos de estrutura centrada na origem e presença. O significado e as formas tornam-se híbridas, fluidas e movediças, passando a existir enquanto construção substitutiva.

${ }^{6}$ Tanto em Critique et vérité, Essais critiques e mais adiante em $S / Z$ e Plasir du texte, Barthes já atenuava para as questões distintivas entre os textes légibles e textes escriptibles: aqueles primeiros só permitem uma representação, e o leitor é um receptor passivo dos conteúdos que, geralmente, são de caráter mimético e realista; estes, são aqueles textos que permitem a re-apresentação, cujo o objeto é a sua própria construção e se prestam à crítica num eterno presente, ou seja, ele é a escritura: “[...] o texto escriptível é nós escrevendo, antes que o jogo infinito do mundo (o mundo como um jogo) seja atravessado, cortado, detido, plastificado por algum sujeito singular (ideologia, gênero, crítica) que feche a pluralidade das entradas, a abertura das redes, o infinito das linguagens. O escriptível é o romanesco sem o romance, a poesia sem o
} 
os acontecimentos em séries não estão presos a uma "realidade" específica e/ou a um tempo histórico engessado.

Na narrativa de Maranhão, a mescla, no enredo ficcional, de fatos históricos, fatos biográficos de Machado de Assis, personagens históricos da esfera política e intelectual brasileira, personagens literários da ficção machadiana e excertos que "simulam" ser retirados das narrativas do escritor fluminense. $\mathrm{E}$ todos esses fatos e aspectos são postos em xeque pela paródia e pela ironia com suas arestas avaliadoras, segundo as constatações de Hutcheon (2000), por tratarmos, sobretudo, no romance Memorial do fim, de estratégias discursivas que promovem relações plurais e dinâmicas entre o texto e o contexto.

Além disso, o romance de Maranhão recria e reavalia o passado histórico e literário brasileiro por meio de traços da metaficção e da metaficção historiográfica que estão presentes no enredo dessa ficção-crítica que, como bem entende Perrone-Moisés (2011), a narrativa, em si mesma, é significação, cujo ideal é destacar a produção de sentidos.

Atentemo-nos, então, às noções de jogo e sentido aplicadas ao romance de Maranhão como sendo aquelas que acontecem como puro devir, devenir, apresentação ou transformação ${ }^{7}$. Isso nos direciona para o fato de que trataremos de um tipo de ficção que Perrone-Moisés (2005) chamou de ficção-crítica ou crítica-escritura: a atividade crítica como uma atividade escritural romanesca. Na crítica tradicional ou na "velha crítica", como define Barthes em Crítica e verdade (Critique et verité) (2011), havia a separação entre leitura e crítica. Com o advento das teorias da escritura e, mais especificamente, com as teorias pós-estruturalistas, principalmente com os estudos de Barthes e Derrida, uniram-se, no mesmo texto e no mesmo tempo, a noção de ler, escrever, reler, reescrever, teorizar e criticar. É, analogicamente, nesta ótica, que a noção de “dobra” de Gilles

poema, o ensaio sem a dissertação, a escritura sem o estilo, a produção sem o produto, a estruturação sem a estrutura". (PERRONE-MOISÉS, 2005, p. 43)

${ }^{7}$ Adotamos essa noção, a de devir e seus sinônimos como acontecimentos puros, a partir dos estudos de Gilles Deleuze (2011), principalmente de sua obra A lógica do sentido. Nessa obra, Deleuze discute o romance Alice no país das maravilhas e trata dos acontecimentos da narrativa a partir de uma série de paradoxos. O primeiro paradoxo é o puro devir, ou seja, a transformação de uma coisa que se torna outra coisa ao mesmo tempo e no mesmo lance. Segundo Deleuze $(2011$, p. 1): "Tal é a simultaneidade de um devir cuja propriedade é furtar-se ao presente. Na medida em que se furta ao presente, o devir não suporta a separação nem a distinção do antes e do depois, do passado e do futuro. Pertence à essência do devir avançar, puxar nos dois sentidos ao mesmo tempo: Alice não cresce sem ficar menor e inversamente. O bom senso é a afirmação de que, em todas as coisas, há um sentido determinável; mas o paradoxo é a afirmação dos dois sentidos ao mesmo tempo". 
Deleuze, principalmente em Leibniz e o Barroco nos é útil ${ }^{8}$. O texto dobra em si mesmo para questionar seus processos inerentes de construção e de problematização do que seria "real" ou "mimético".

Juntamente à ideia de dobra, uniremos as noções de jogo e sentido à noção de escritura $^{9}$ que adotamos, principalmente, dos estudos de Roland Barthes (1970; 2000; 2003; 2004a; 2004b; 2005; 2010; 2011) e de Jacques Derrida (2005; 2008; 2009). Veremos, então, que a escritura, tradução do vocábulo francês écriture ${ }^{10}$, é uma noção hermética dotada de um vazio e de um espaço aberto que sempre exigirá um suplemento a partir da convocação ativa do leitor no jogo textual.

Esta ideia de escritura compartilha com o pensamento de Gilles Deleuze (1991; 1995; 2006; 2010a; 2010b; 2011), Michel Foucault (1992; 1996; 2007), Jacques Lacan (2008), Jean Baudrillard (1991) e Jean François Lyotard (2008), que pensam o texto a partir da diferença e da repetição. A escritura, preliminarmente, é antitotalizante, palimpséstica e singular. Ela descontrói a ideia de real a ser representada ao dobrar-se sobre sua própria composição, tornando visível o que Linda Hutcheon (1984) chamou de

\footnotetext{
${ }^{8}$ Partindo do princípio que a função primordial da teoria pós-estruturalista é reavaliar o estruturalismo e toda a forma de pensamento ocidental no seu sistema interno (PETERS, 2000), a dobra à qual Deleuze (1991) se refere é aquela que questiona a metafísica e transcendência platônica: o importante é voltar-se para a matéria e analisar o sujeito: o mundo está no sujeito e não o contrário. Logo a noção de verossimilhança aristotélica, em narrativas como em Memorial do Fim, caem por terra. O romance voltase para si e questiona todas as possibilidades de referência externas a ele. Para Deleuze (1991, p. 50 - 51), “[...] a 'lei das curvaturas' não está na alma, embora a série o esteja, embora as curvaturas aí estejam. É também nesse sentido que a alma é uma 'produção', um 'resultado': ela resulta do mundo que Deus escolheu. Dado que o mundo está na mônada, cada um inclui toda a série dos estados do mundo; mas, dado que a mônada é para o mundo, nenhuma contém claramente a 'razão' da série, da qual todas elas resultam e que lhes permanece exterior como o princípio do seu acordo. Portanto, passa-se do mundo ao sujeito, ao preço de uma torção que faz com que o mundo só exista atualmente nos sujeitos, mas que faz também que todos os sujeitos sejam reportados a esse mundo como à virtualidade que eles atualizam. [...] A clausura é a condição do ser para o mundo. A condição de clausura vale para a abertura infinita do finito: ela 'representa finitamente a infinidade'. Ela dá ao mundo a possibilidade de recomeçar em cada mônada. É preciso colocar o mundo no sujeito, a fim de que o sujeito seja para o mundo. É essa torção que constitui a dobra do mundo e da alma e é ela que dá à expressão seu traço fundamental: a alma é expressão do mundo (atualidade), mas porque o mundo é o expresso pela alma (virtualidade).

${ }^{9} \mathrm{O}$ advento da escritura na contemporaneidade, assim como bem a entende Leyla Perrone-Moisés (1978; 2005) em Texto, crítica, escritura, marca o fim da literatura como discurso representativo para nascer o "texto".

${ }^{10}$ Écriture pode ser traduzida em português tanto como "escrita" ou "escritura". Interessa-nos aqui discutir a problematização que Barthes faz desta noção. Em Le degrée zero de l'écriture, publicado em 1953, o autor começa a tratar do problema da écriture. A escritura, segundo Perrone Moisés (1978, p. 29), "privilegiará a produção de novos sentidos sobre a reprodução de sentidos prévios, que, ao invés de apenas ajudar a ler (a decifrar), dar-se-á à leitura como um novo ciframento". Barthes desenvolveria a noção de escritura como uma releitura e uma reinvenção crítica a partir das obras Critique et vérité, $S / Z$ e Le plaisir du texte.
} 
mimese do processo. Partindo dos preceitos bakhtianos, o romance Memorial do fim é plurilinguístico e amorfo.

Em busca de uma melhor precisão da noção de escritura que aqui adotamos, primeiramente recorremos a uma das primeiras obras de Barthes, O grau zero da escrita (Le degrée zero de l'écriture). $\mathrm{O}$ autor de $S / Z$ define, previamente, a escrita como o lugar privilegiado entre a língua e o estilo. Barthes (2000, p. 13) assegura que a língua e estilo são objetos. A escrita é uma função. O que falta ainda a Barthes, preso ao estruturalismo, é problematizar a escrita para torná-la uma écriture. Constatamos que Barthes (2000), ao longo das reflexões contidas em $O$ grau zero da escrita ${ }^{11}$, procura esclarecer o que seria a escrita e, também, em vários momentos do texto, o que seria o estilo, embora não precise essas noções. A noção de escrita aparece como "uma realidade ambígua: por uma parte nasce incontestavelmente de um escritor com a sociedade; por outra, dessa finalidade social, ela remete o escritor, por uma espécie de transferência trágica, às fontes instrumentais de sua criação". (BARTHES, 2000, p. 13). A escrita também aparece nesse estudo como um compromisso entre uma "liberdade" e uma "lembrança" que acontece no gesto da escolha. Por fim, o romance para Barthes (2000, p. 36 - 37) é uma morte, uma vez que a escrita romanesca faz da vida um destino, das lembranças e das memórias um ato útil e da duração um tempo dirigido e significativo. A sociedade impõe na escrita do romance um complexo de signos como transcendência e como História de uma duração.

Comecemos a perceber a importância de algumas reflexões desenvolvidas por Barthes já em $O$ grau zero da escrita que serão fundamentais à noção de escritura que empregaremos em nossa tese: o problema da criação, da transformação, da liberdade e da escolha. Foi no aprofundamento das leituras das obras de Barthes que percebemos, já no texto "A morte do autor", de 1968 - integrado à obra O rumor da língua - a gênese para a teoria da escritura: a destruição do fonocentrismo e do abandono das teorias platônicas do ser como ideia e origem. É exatamente a partir desta perspectiva que Barthes começa a dialogar com os pensadores pós-estruturalistas, principalmente com Derrida, nos seus estudos A escritura e a diferença, A farmácia de Platão e em Gramatologia. Ao questionar a posição autoral como uma entidade inabalável, “a escritura é a destruição de

\footnotetext{
${ }^{11} \mathrm{Na}$ edição publicada em 2000 pela Martins Fontes e traduzida por Mário Laranjeira, écriture é traduzida por escrita.
} 
toda a voz, de toda a origem. A escritura é esse neutro, esse composto, esse oblíquo pelo qual foge nosso sujeito, o branco-e-preto e que vem se perder toda a identidade, a começar pela do corpo que escreve" (BARTHES, 2004b, p. 57). E o autor de $O$ grão da voz encerra o texto com uma informação valiosa: "Sabemos que, para desenvolver ou devolver? conferir à [sic] escritura o seu futuro, é preciso interver idem no mito: o nascimento do leitor deve pagar-se com a morte do autor". (BARTHES, 2004b, p. 64)

O papel ativo do leitor: eis aqui um dos aspectos basilares para o exame do romance Memorial do fim. Estamos nos referindo aos estudos de Jauss (1979) e de Iser (1979) sobre a estética da recepção. Juntamente às pesquisas desenvolvidas em torno dos aspectos da linguística por Barthes e do texto literário propriamente dito, a estética da recepção, surgida em 1967, redescobre o leitor que passa a articular os sentidos do texto sem deixar de lado a qualidade estética. Essa modificação nas formas de leitura e na atribuição de sentidos é análoga ao que Robert Scholes (1967) entende como ato de criação literária feita pelos fabulators. Estes seriam aqueles autores que transformariam o ato da leitura em uma experiência mágica. Scholes (1967, p. 3) explica que a crítica tradicional presumia maneiras de como ler e interpretar uma obra literária. A mudança, a partir dos "fabuladores" e mais intensamente com a metaficção pós-moderna, se daria a partir do momento em que o leitor fizesse parte da própria estrutura da obra, integrandoa.

Mediada pelo leitor, os sentidos são múltiplos e variáveis. Se a escritura é uma percepção, uma leitura, ou melhor, uma releitura, os significados são engendrados pelos processos de interpretação. E com a interdisciplinaridade das ciências humanas com as letras, principalmente da História com a Literatura, essas duas áreas começaram a se mesclar e transpor limites que eram até então definidos. A escritura age no romance Memorial do fim, enquanto noção pós-estruturalista, como um amálgama, um pastiche (HOSTEREY, 2001) e uma mistura [mélange] (PROUST, 2009) do fato histórico unido às estratégias da narrativa ficcional. E não só isso: há o hibridismo de gêneros documentais como as cartas, os diários, as biografias, as autobiografias e memoriais entendidos por Foucault (2010) como “escritas de si” que são romancizadas e problematizadas enquanto arquivo histórico no enredo ficcional.

Memorial do fim incorpora as escritas de si como uma maneira de revisar o passado histórico, literário e, ao mesmo tempo, de problematizar a natureza ficcional de 
suas produções. Por isso, o passado revisto e reinterpretado por Maranhão é reescrito a partir das manifestações intimistas de personalidades históricas e literárias que são convocadas a fazer parte do Memorial, no qual há trechos de cartas, páginas de diários e outras formas de "representar" uma possível história machadiana.

Todas essas revisões e mesclas são propiciadas por meio do "jogo do texto" apresentado por Iser (1979) na estética da recepção. Partindo das indagações de Iser, entendemos que o sistema fechado - tanto do documento histórico como da ficção que se vinculava à crítica imanentista positivista - é perfurado e substituído por um sistema aberto. Isso compromete o mimestismo aristotélico e o aspecto performativo do jogo assume o primeiro plano. A escritura é feita pela indeterminação resultante da redução do texto às próprias experiências da leitura, ou seja, o leitor conecta suas experiências às suas próprias representações do mundo ou do texto. Logo, a escritura romanesca de Maranhão é uma arena montada para o jogo. Por esta razão,

\footnotetext{
caberá ao leitor suplementar o(s) vazio(s) assim criado(s) pois, do contrário, o enredo não fluirá. Diz-se suplementá-lo(s) e não o(s) complementar, pois, ao contrário de uma quebra cabeças, não há uma única maneira correta de fazêlo. Os lugares vazios, em suma, apresentam a estrutura do texto literário como uma articulação de furos, que exige do leitor mais do que a capacidade de decodificação. A decodificação diz respeito ao domínio da língua. O vazio exige do leitor uma participação ativa. (COSTA LIMA, 1979, p. 26)
}

A escritura para Barthes, de acordo com Perrone-Moisés (2012, p. 70) é "um discurso em que as palavras são usadas como instrumentos, mas encenadas, teatralizadas como significantes. Toda escritura é, portanto uma escrita, mas nem toda escrita é uma escritura". E a autora ainda afirma: "a escritura é transbordamento, arrebatamento do estilo para outras regiões da linguagem e do sujeito, longe do código literário classificado" (PERRONE-MOISÉS, 2012, p. 70). A noção de escritura execra os preceitos platônicos e hegelianos de estrutura rígida e centralizada em torno do sujeito. Interessa a plurissignificação do texto e a sua intertextualidade. A escritura se dá na fronteira, no não-lugar, nas séries móveis, ou como prefere Silviano Santiago (2002), no "entre-lugar". 
A escritura é "ex-cêntrica" (HUTCHEON, 1991) e apresenta uma pluralidade estrutural que está diretamente ligada à pluralidade de sentido. Perrone-Moysés (2012, p. 32) argumenta com base na obra $S / Z$, que esta vertente plural da escritura está relacionada ao fato de ela, a escritura, apresentar uma "rede de mil entradas". E para a estudiosa barthesiana, os códigos ${ }^{12}$ não constituem uma estrutura rígida, centrada ou relacionada à identidade do sujeito ou aos nomes próprios que aprisionam. Mas, pela sua fluidez, pelo seu teor autorreflexivo e problematizador, a escritura ressignifica os códigos da história e da literatura, bem como os da vida empírica, em uma imensa teia de citações, tornandoos uma miragem de estruturas móveis e transcontextualizadas (HUTCHEON, 1985). A nosso ver, a imagem do palimpsesto genettiano nos parece esclarecedora para visualizar esse aspecto da escritura ficcional. O outro texto, ou melhor, os códigos do outro texto aparecem no hipertexto contemporâneo através da paródia, da ironia, do pastiche ou por meio da transgressão risível e cômica.

A problematização dos códigos desprovidos dos sentidos totalizantes é uma das preocupações centrais do pós-estruturalismo. Gilles Deleuze (2011) em A lógica do sentido assevera que os códigos devem apresentar-se como puros acontecimentos, um devir-louco que substitui as dualidades. Os códigos começam a trabalhar na fronteira entre as coisas e a proposições. As palavras e coisas. Parafraseando Foucault (2007), livre da relação, a representação literária transforma-se em pura apresentação. Eles, os códigos, se interpenetram e se chocam criando novos acontecimentos.

Os códigos são, para Deleuze, signos nos quais os significantes são desprovidos de significados. Veremos que a retomada dos códigos puros será primordial na escritura de Maranhão ao passo que forma a singularidade ${ }^{13}$. O retorno de Machado de Assis no "anti-enredo" de Memorial do fim não é uma repetição da cópia ou uma continuação de uma narrativa nostálgica em relação a não consolidação de um cânone na contemporaneidade. O retorno é do código, isto é, do signo desprovido do significado primeiro.

\footnotetext{
${ }^{12}$ Perrone-Moisés se refere aos códigos de Sarrazine, de Balzac examinados na obra $S / Z$ de Barthes.

${ }^{13}$ Deleuze trata das singularidades como partes integrantes das estruturas em séries paradoxais. Segundo o filósofo francês, "as singularidades-acontecimentos correspondem a séries heterogêneas que se organizam em um sistema nem estável nem instável, mas "metaestável", provido de uma energia potencial em que se distribuem as diferenças entre séries". (DELEUZE, 2011, p. 106). Em outras palavras, a singularidade presente na escritura estaria na criação de sentidos originais criados na superfície, uma vez que os signos estão desprovidos de um sentido total.
} 
Em Memorial do fim, Maranhão se refere a Machado de Assis ora como Conselheiro Ayres, ora como Bruxo do Cosme Velho ou simplesmente como um moribundo que está deixando de viver. A narrativa é suplementada por uma escritura híbrida que reflete sobre o papel do escritor contemporâneo, sobre a forma dos gêneros literários, sobre a validade dos fatos históricos e documentais e sobre a própria criação ficcional como um todo. O Machado de Maranhão não tem lugar e nem nome próprio. Ele está "desterritorializado", no sentido empregado em $O$ anti-édipo de Deleuze e Guattari (2010). É um corpo sem órgãos ou uma máquina desejante com fluxos descontínuos. Nesses entretempos, o que o leitor se depara é com uma tentativa esquizoide de uma instância narrativa que tenta descrever uma "biografia". Porém, a fragmentação e o "horror à linha reta" (PAES, 1998) ou a "reta desdenhada" (COSTA LIMA, 2009), herdados de Tristram Shandy, criam uma anti-biografia, haja vista que o suposto enredo não narra uma história de vida, apenas menciona fatos históricos sem sequência lógica ou em uma cronologia definida. Há digressões, pausas, hiatos e questionamentos.

A fabulação de Maranhão cria um heterocosmo de signos nos quais os significados são desprovidos do sentido primeiro e passam a funcionar como "significantes dos significantes" (DERRIDA, 2008). Por esse motivo, Machado da Assis é o Conselheiro Aires que é o Aguiar e que é o Bruxo do Cosme Velho - apelido dado por Carlos Drummond (PIZA, 2008) - também e, ao mesmo tempo, ele é uma síntese e uma mescla de suas personagens que reaparecem e cruzam consigo no enredo por meio dos recortes e das emendas textuais e pastiches da obra ficcional machadiana. Em meio a tudo isso, a presença da morte e do tom biográfico que tenta "recontar" os derradeiros dias do escritor fluminense são problematizados pela escritura especular que põe em xeque o realismo do século XIX ao refletir sobre a própria escritura do romance, tal como Machado de Assis o fizera em grande parte de sua obra madura, principalmente em Esaú e Jacó, Memórias Póstumas de Brás Cubas, Dom Casmurro e em Memorial de Aires.

O romance de Maranhão execra qualquer possibilidade de referencialidade porque ele é um lance feito num "jogo de acontecimentos puros" e a partir de uma "série de paradoxos" (DELEUZE, 2011). A cada leitura, os leitores atribuem novos "sentidos" aos arranjos textuais. No excerto abaixo, o narrador, à maneira imitativa do próprio Machado, 
coloca um capítulo desconexo que não tem relação alguma com o capítulo anterior e, consequentemente, com o posterior:

\author{
Capítulo XIS \\ Que sucede ao XII e antecede ao XIV
}

Peremptoriamente a prudência manda eliminar o caput deste capítulo, na ordenação romana, que se preferiu à cardinal. O número Xis, ora interdito, pode nem ser de agouros nefastos; mas pode ser.

Duas teses sustentam-se sobre a matéria em si, entre si antíteses. Elas miramse com o ânimo do desafio. Não recomendo que se adote a primeira; nem tampouco a segunda, pelo avisado temor de que a verdade verdadíssima more na oposta.

Não me inclinaria eu por uma ou outra proposição, pela causa de termos por cá morimbundo. E qualquer dos enunciados, seja A ou seja B, um suprimará horas ao decesso; o outro acrescentará.

Abre-se agora nova controvérsia: qual dos resultados convirá ao interessado mais próximo, isto é, ao moribundo? (MARANHÃO, 2004, p. 53)

A autorreferencialidade explícita neste capítulo é semelhante à autoconsciência narrativa presente nas Memórias Póstumas de Brás Cubas e em outros romances machadianos e, mesmo antes dele, como em Tristram Shandy, por exemplo. A técnica da digressão, tão comum em Sterne, Cervantes, Maîstre e na própria ficção machadiana é, agora, resgatada por Maranhão e apresenta um grau mais crítico, posto que o tempo todo o texto é entrecortado por signos que marcam a diferença na repetição. Nisto consiste a "superioridade da arte sobre a vida: todos os signos que encontramos na vida ainda são signos materiais e seu sentido, estando sempre em outra coisa, não é inteiramente espiritual". (DELEUZE, 2010a, p. 39)

Por meio dessa dicção biográfica, embora permeada pelos intervalos digressivos, os leitores acostumados com os enredos lineares ficam desnorteados com o aspecto esquizoide do tecido narrativo de Maranhão. Vejamos, por exemplo, o encadeamento dos capítulos iniciais e como o romance se inicia.

A “cena" - se é que essa palavra pode ser aplicada ao jogo de Maranhão - que abre o primeiro dos cinquenta e quatro capítulos da diegese já instaura o impasse das misturas: o título do primeiro capítulo é "Dona Marcela" e a primeira frase do capítulo é 
a fala "nunca me há de esquecer este dia". Logo em seguida, o narrador insere a figura de José Veríssimo de Matos, que era um grande amigo de Machado de Assis e que esteve presente em vários momentos da vida deste, como bem apontou Miguel-Pereira (1988) e Daniel Piza (2008). Até aqui, três problemas são detectados: a presença da ficção machadiana dentro da ficção de Maranhão e a articulação de uma personagem biográfica e histórica inserida e aliada ao heterocosmo fictício. Para problematizar ainda mais e destruir as ilusões referenciais, a voz narrativa apenas destaca a presença desarticulada de José Veríssimo que fora visitar o "semi-morto" e passa, no mesmo momento e ao mesmo tempo, simultaneamente, a discutir questões de ordem metaficcional à maneira shandiana:

A casa do morador sozinho havia alterado as práticas, que vinham do ministério Zacaraias. A questão atinha-se ao descimento da escada. Descer e subir escadas é assunto manso; é deliberação visceral que tange raias inauditas. Subir escadas, descê-las, é matéria para um tomo ou dois, e não para linhas distraídas de um capítulo. Só se descem escadas após repensadas reflexões, e a decisão é uma decisão que transcende os máximos limites. (MARANHÃO, 2004, p. 12)

Os comentários sobre os atos efêmeros de descer e subir escadas tiram o foco central do parágrafo anterior que anunciara a chegada de Veríssimo ao Chalet próximo aos Bonds e frente a tantas cousas que acontecem como lances feitos num jogo repetido e simultâneo. Desde a primeira linha do romance, a narrativa se manifesta como um eterno devir no qual tudo acontece sem a pretensão de criar um sentido total ou unificado. Os vários sentidos dessa ficção que se autorrepete com diferença é construída por meios dos paradoxos e, principalmente, por meio da ironia. Aliás, a questão da ironia e do riso melancólico são as tônicas mais observáveis e mais trabalhadas no engenho ficcional de Maranhão, uma vez que sua transgressão é avaliada nos atos intencionais e de referência. A ironia se manifesta em Maranhão por meio de um processo ativo de atribuição e interpretação, ou seja

a ironia, então, significará coisas diferentes para diferentes jogadores. Do ponto de vista do interpretador, a ironia é uma jogada interpretativa e intencional: é a criação ou inferência de significado em acréscimo ao que se afirma - e diferentemente do que se afirma - com uma atitude para o dito e o não dito. A jogada é geralmente disparada (e, então, direcionada) por alguma 
evidência textual ou contextual ou por marcadores sobre os quais há concordância social. [...] A ironia é a transmissão intencional tanto da informação quanto da atitude avaliadora além do que é apresentado explicitamente. (HUTCHEON, 2000, p. 28)

Pelos acréscimos, supressões, transmissões intencionais, jogadas interpretativas e pelas evidências textuais tanto da ficção, quanto da biografia de Machado, os jogos irônicos se articulam em todos os discursos materializados no romance, desde os comentários sobre a saúde frágil do epiléptico até os enxertos de gêneros intimistas, como cartas e partes de diário em capítulos que alternam as cenas irônicas. Nessas trocas, também são acrescidas partes que, em um primeiro momento, parecem ser recortes e colagens de partes específicas de capítulos de Memórias Póstumas, Dom Casmurro, Quincas Borba e do Memorial de Aires. Mas, se verificarmos com mais acuidade, é notório que a instância apenas intercala vestígios e significantes dos significantes machadianos para poder criar um "último" memorial. E esta ideia do "último" memorial era, não menos, o título provisório que Machado daria ao romance Esaú e Jacó, publicado em 1904 e que, por esta razão, não foi o derradeiro.

Essa ideia da continuidade e da repetição com diferença, que marca o não fim porque "não se pinga o ponto final", perpassa toda a narrativa, desde os parágrafos iniciais até as últimas frases. Ainda no primeiro capítulo,

pratica-se o exercício do pudor uma vida inteira; mas lá um dia caem os panos do teatro: e então a pudicícia cala, e conforma-se. Ora, ora, pudores. Ocasião virá em que pudores não serão mais que memórias, e memórias são memórias. Os lutos, sendo lutos, não seguem eternos. Após a missa de sétimo dia, sobrevém o oitavo dia e logo acerca-se o trigésimo; e após essa eternidade de trinta dias, qualquer ação de choro será choro de ópera italiana, quando nunca se sabe se o soprano chora ou gargalha, ou se põe no proscênio ambas as farsas. Mis, dós e fás favorecem lágrimas e por igual não militam em desfavor dos gáudios. (MARANHÃO, 2004, p. 12)

A melancolia satirizada no trecho anterior a respeito dos lutos eternos e o tratamento da morte como um fim em si mesmo também são matéria para a avaliação das cenas transideológicas da ironia. Como exemplificação, vejamos a primeira menção 
"biográfica" de Machado marcada pelo tom niilista e pelo riso amargo semelhante àquele contido em Brás Cubas:

Degrau a degrau, o dormitório descera os dois lances da escada de cerejeira. $\mathrm{O}$ à-vontade de cima mudara em constrangimentos no gabinete do rés-do-chão. Aqui, o enfermo sujeitava-se a mal dormir e a finar sem conforto e sem paz, afligido de vexames. Tossir e gemer são atos privados. Haverá quem não se peje de fazê-lo à vista dos mais apaixonados pela amizade. Há mais impudicos que estrelas num palmo de firmamento. Gemidos podem sempre ocultar-se atrás dos dentes soldados; já tossir é compulsão, e a tosse pula-nos da laringe como rã. A tosse é mulher palreira, que fácil se desconcerta nos mercados de peixe. Ora tosses, ora gemidos, ora a roupa enxovalhada do suor noturno, ora um corpo de ancião nuamente entremostrado! (MARANHÃO, 2004, p. 12)

Pormenores e descrições irônicas, niilistas e melancólicas como essas a respeito da condição do conselheiro estão dilaceradas por toda a narrativa. O capítulo $\mathrm{V}$, intitulado "um certo calvo", demonstra o fel melancólico do "Conselheiro Aires", agora voltado à sua própria reconstituição fictício biográfica:

O moribundo via-se mesmo, como ficara, na comoção mostrada pelos outros; sentia que as carnes minguavam, que os vermes alvoroçavam pelo roer das carnes do defunto que não se fizera ainda em defunto, porém na iminência dele, já no estado de esqueleto, que um nada de nada se mexia; mas se mexia. “A vida é boa", em dados momentos animava-se. Retrocedia no tempo. Ia, tornava, de novo ia, de novo tornava. Repôs-se à beira da enxerga onde um companheiro putrefeito despedia o último arranco. O último arranco? Não mais que duas semanas depois, quem reencontro ao sair da Garnier? O escrofuloso, o vice-morto, notavelmente reganhado de alentos e de untos, rilhando um charuto, que denunciava o fino almoço de que emergia, um bife cru for ever de que o rosto beato dava bom sinal. [...] Será? Será o quê?, voz anônima vivamente respondeu-lhe ao pé do ouvido, a um pensamento apenas debuxado. A tosse raivosa aplaca-se, quando mais não for da fadiga de tossir, tossir, tossir. O cancro sacia-se; pode saciar-se; tem sucedido que se sacie. Tornarei ao ministério, à Lambaerts, ao Pascoal, à avenida?

(MARANHÃO, 2004, p. 28) 
Os acontecimentos relativos ao definhamento machadiano são acompanhados por inúmeros personagens que transitam livremente entre os mundos da ficção e da história, no ano de 1908, mais especificamente, entre os meses de abril a setembro. Personalidades históricas são inseridas no enredo, como o já citado José Veríssimo, e tantos outros amigos de Machado, principalmente aqueles pertences à Academia. Aparecem em forma de cartas ou em formas de visitas ao moribundo na casa à Rua do Cosme Velho, como no caso do Dr. Mário de Alencar, o Joaquim Nabuco - com quem Machado trocava cartas na vida real - e de Astrogildo Pereira, do Barão do Rio Branco, Euclides da Cunha, Olavo Bilac e Alberto de Oliveira. Também fazem, parte do enredo pessoas que conviviam com Machado de Assis, como a criada Jovita Maria de Araújo e Leonora, que ora se apresenta como Marcela ou Hylda, além de outras personagens que vão aparecendo no romance à medida que o romancista se despede da vida.

\section{"Não se pinga o ponto final"14}

Nesta escritura que dobra sobre si mesma, detectamos aquilo que Foucault (2006, p. 25) definiu como "repetir incansavelmente aquilo que, no entanto, não havia jamais sido dito". Ou seja, em críticas-escrituras como o Memorial do fim, o texto é tudo: nele aprendemos a ver o outro de outra forma e a nós mesmos de forma autorreflexiva. Nessa tentativa diferente, porém repetida, findamos, por ora, nossas reflexões com a frase de Euclides da Cunha ao visitar o leito de morte na ficção de Maranhão:

\footnotetext{
- Qualquer que seja o destino dessa criança, ela nunca subirá tanto na vida. Naquele meio segundo, no segundo em que ele estreitou o peito moribundo de Machado de Assis, aquele menino foi o maior homem de sua terra. Pelos nossos olhos passou a impressão visual da Posteridade. (MARANHÃO, 2004, p. 191)
}

E, com esse mesmo anseio de nosso exame crítico ficar à posteridade, mesmo com nossas frágeis e, às vezes, pretenciosas tentativas de dialogar com as teorias pósestruturalistas, com a historiografia juntamente à crítica literária, esperamos ter contribuído com a fortuna crítica de Haroldo Maranhão. E, então, um último suspiro: "Ele

${ }^{14}($ MARANHÃO, 2004, p. 181) 
[Conselheiro/Machado/Ayres/Aguiar] se despedia. Permaneceu de joelhos fitando-me pela última vez. Beijou-me a mão. Vi que não suportou o peso das lágrimas. Não chegou a perceber que eu também chorava”. (MARANHÃO, 2004, p. 190). Aqui, findamos nossa leitura...

\section{REFERÊNCIAS}

ALVES, Sérgio. Fios da memória, jogo textual e ficcional de Haroldo Maranhão. Belo Horizonte: Faculdade de Letras da Universidade Federal de Minas Gerais, 2006. (Tese de doutorado)

ASSIS, Machado de. Contos: uma antologia. São Paulo: Companhia da Letras, 1998.

Dom Casmurro. São Paulo: Martins Fontes, 2003. Esaú e Jacó. São Paulo: Penguin Classics/Companhia das Letras, 2012. . Memorial de Aires. Rio de Janeiro: Nova Fronteira, 2013. . Memórias Póstumas de Brás Cubas. São Paulo: Globo, 2008.

BARTHES, Roland. A preparação do romance I: da vida à obra. Tradução Leyla PerroneMoisés. São Paulo: Martins Fontes, 2005.

.O grão da voz. Tradução Mário Laranjeira. São Paulo: Martins Fontes, 2004a.

. O grau zero da escrita. Tradução Mário Laranjeira. São Paulo: Martins Fontes, 2000.

_. O prazer do texto. Tradução J. Guinsburg. São Paulo: Perspectiva, 2010.

$\overline{2004 b .}$

. O rumor da língua. Tradução Mário Laranjeira. São Paulo: Martins Fontes,

Roland Barthes por Roland Barthes. Tradução Leyla Perrone-Moisés. São Paulo:

Estação Liberdade, 2003.

_. S/Z. Tradução Maria de Santa Clara e Ana Mafalda Leite. Lisboa: Edições 70, 1999.

COSTA LIMA, Luiz. História. Ficção. Literatura. São Paulo: Companhia das Letras, 2006.

DELEUZE, Gilles. A ilha deserta: e outros textos. Tradução Luiz B. L. Orlandi. São Paulo: Iluminuras, 2006.

. Diferença e repetição. Tradução Luiz Orlandi e Roberto Machado. Rio de Janeiro: Graal, 2006.

Leibniz e o barroco. Tradução Luiz B. L. Orlandi. Campinas, SP: Papirus, 1991.

2011 Lógica do sentido. Tradução Luiz Roberto Salinas Fortes. São Paulo: Perspectiva, 
Proust e os signos. Tradução Antonio Carlos Piquet e Roberto Machado. Rio de Janeiro: Forense Universitária, 2010a.

DELEUZE, Gilles; GUATTARI, Félix. Mil platôs: capitalismo e esquizofrenia. Tradução de Ana Lúcia de Oliveria, Aurélio Guerra Neto e Célia Pinto Costa. São Paulo: Editora 34, 1995.

O anti-épido: capitalismo e esquizofrenia. Tradução de Luiz B. L. Orlandi. São Paulo: Ed. 34, 2010b.

DERRIDA, Jacques. A escritura e a diferença. Tradução Pérola de Carvalho, Maria Beatriz Marques e outros. São Paulo: Perspectiva, 2009.

. A farmácia de Platão. Tradução Rogério da Costa. São Paulo: Iluminuras, 2005.

Gramatologia. Tradução Miriam Schnaiderman e Renato J. Ribeiro. São Paulo:

Perspectiva, 2008.

ESTEVES, Antonio. O romance histórico brasileiro contemporâneo. São Paulo: Editora Unesp, 2010.

FOUCAULT, Michel. A escrita de si. In: Ditos e escritos V: Ética, sexualidade, política. Rio de Janeiro: Forense Universitária, 2010, 144 - 162.

Estruturalismo e Pós-estruturalismo. In: Ditos e escritos II: Arqueologia das ciências e história dos sistemas de pensamento. Tradução Elisa Monteiro. Rio de Janeiro: Forense Universitária, 2000, p. 307 - 366.

GARRAMUÑO, Florencia. Frutos estranhos: sobre a inespecificidade na estética contemporânea. Rio de Janeiro: Rocco, 2014.

GENETTE, Gérard. Palimpsestes: la littérature au second degré. Paris: Éditions du Seuil, 1982.

HUTCHEON, Linda. Narcissistic narrative: the metafictional paradox. New York: London, Methuen, 1984.

Poética do pós-modernismo: história, teoria e ficção. Tradução Ricardo Cruz. Rio de Janeiro: Imago Ed., 1991. Teoria e política da ironia. Tradução Júlio Jeha. Belo Horizonte: Editora UFMG, 2000

Uma teoria da paródia: ensinamentos das formas de arte do século XX. Tradução Tereza Louro Peres. Lisboa: Edições 70, 1985.

ISER, Wolfgang. O jogo do texto. In: JAUSS, Hans et alii. A literatura e o leitor: textos de estética da recepção. Tradução Luiz Costa Lima. Rio de Janeiro: Paz e Terra, 1979, p. $105-118$.

KLINGER, Diana. Escritas de si, escritas do outro: o retorno do autor e a virada etnográfica. Rio de Janeiro: 7 Letras, 2012.

LACAN, Jacques. Escritos. Tradução Inês Oseki-Depré. São Paulo: Perspectiva, 2008. 
MARANHÃO, Haroldo. Memorial do fim: a morte de Machado de Assis. São Paulo: Marco Zero, 1991.

Memorial do fim: a morte de Machado de Assis. São Paulo: Planeta, 2004.

PAES, José. Sterne ou o horror à linha reta. In: STERNE, Laurence. A vida e opiniões do cavaleiro Tristram Shandy. Tradução José Paulo Paes. São Paulo: Companhia das Letras, 1998, p. 7 - 38.

PEREIRA, Lúcia Miguel. Machado de Assis: um estudo crítico e biográfico. Belo Horizonte: Itatiaia; São Paulo: Editora da Universidade de São Paulo, 1988.

PERRONE-MOYSÉS, Leyla. Apresentação. In: BARTHES, Roland. Crítica e verdade. Tradução Leyla Perrone-Moisés. São Paulo: Perspectiva, 2011, p. 7 - 12.

. Com Roland Barthes. São Paulo: Martins Fontes, 2012.

Pós-estruturalismo e desconstrução nas Américas. In: PERRONE-MOISÉS, Leyla. (Org.). Do positivismo à desconstrução: ideias francesas na América. São Paulo: Editora da Universidade de São Paulo, 2004.

. Texto, crítica, escritura. São Paulo: Ática, 1978.

Texto, crítica, escritura. São Paulo: Martins Fontes, 2005.

O novo romance francês. São Paulo: S.A., 1966.

PETERS, Michel. Pós-estruturalismo e filosofia da diferença. Tradução Tomaz Tadeu da Silva. Belo Horizonte: Autêntica, 2000.

PIZA, Daniel. Machado de Assis: um gênio brasileiro. São Paulo: Impressa Oficial do Estado de São Paulo, 2008

PROUST, Marcel. Pastiches et mélanges. Paris: Éditions L'imaginaire Gallimard, 2009. ROUANET, Sérgio. Riso e melancolia. São Paulo: Companhia das letras, 2007.

SCHOLES, Robert. The fabulators. New York: Oxford University Press, 1967.

STERNE, Laurence. Vida e opiniões do cavaleiro Tristram Shandy. Tradução José Paulo Paes. São Paulo: Companhia das Letras, 1998. 